\title{
Survey of Patient Satisfaction with Radiological Services in Public and Private Health Facilities in Kano
}

1 Lydia A. Gana

1 Mustapha Barde

2 Chigozie I. Nwobi

1 Joseph D. Zira

3 Musa G. Lalai

1 Mohammad Sidi

1 Emmanuel I. Richard

1 Department of Medical Radiography, Faculty of Allied Health Sciences, College of Health Sciences Bayero, University Kano

2 Department of Medical Radiography, College of Medical Sciences, University of Maiduguri, Borno State

3 Department of Nursing Services, Abubakar Tafawa Balewa Universty Teaching Hospital, Bauchi, Bauchi State.

\section{Abstract}

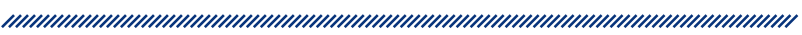

Background: Patient satisfaction is the extent to which the patients feel that their needs and expectations are being met by the service provider. The survey of patient satisfaction with health care services is a growing concept in Nigeria, where study on this subject is just beginning to develop.

Objective: The aim of this study was to compare the patients' satisfaction level with radiological services and to identify the factors that may account for the differences in their satisfaction between a public and a private health facility in Kano state Nigeria.

Method: The study was a cross-sectional prospective survey that targeted patients who visited radiology departments. Data was collected using a 43 item self-completion questionnaire designed in line with the objectives of the study. The data were categorized into groups and analysed using a statistical package for social sciences version 20.0, where descriptive statistics such as the percentages and frequencies were generated and tabulated. A chi-square test was used to test for the differences in the patients' satisfactory level at $(p<0.05)$.

Results: The results showed that $60.7 \%(n=85)$ were female while $39.3 \%(n=55)$ were male, $52.2 \%(n=47)$ of the respondents from the public hospital were dissatisfied, while $47.8 \%(n=43)$ were satisfied. At the private hospital, only $20 \%(n=10)$ were dissatisfied, while $80 \%(n=40)$ were satisfied with the radiological services received. The type of health facility and patients' satisfaction was found to be statistically significant at $(p<0.05)$.

Conclusion: The patients in the private health facility of the study were more satisfied than those at the public health facility because of prompt attention given to them immediately after arrival, immediate collection of their radiological reports, and high ergonometric environment provided by the hospital staff.

Keywords: patient satisfaction, radiology services, public and private facility

Article received: 20.11.2019.

Article accepted: 31.01.2020.

https://doi.org/10.24141/1/6/1/3

Corresponding author:

Joseph D. Zira

E-mail: josephdlama@gmail.com

Phone: +2348130582721 


\section{Introduction}

The survey of patient satisfaction with health care services is a growing concept in Nigeria, where study on the subject is just beginning to develop. Patient satisfaction with health care services has not been given the attention it deserves, let alone the comparison of institutional differences on the subject ${ }^{1}$. It has been defined that patient satisfaction is the extent to which the patients feel that their needs and expectations are being met by the service provider ${ }^{2}$. With numerous assessment measures, consumer satisfaction which overlaps responsiveness in various dimensions is one of the important evaluation measures of quality and performance of any health system ${ }^{3}$. Similarly, 'legal' expectations about service quality also serve as an important tool in understanding patients' ambition and needs for better health care. The evaluation of services offered and consumer satisfaction is, therefore, a dynamic rather than a static process $^{3}$.

Radiological services can simply be said to be the services which are rendered to a patient visiting the radiology department, which can either be routine services, that is, those carried out on a day to day basis, or some special examinations that are carried out in special cases that require the use of contrast agents ${ }^{1}$. Despite extensive research done on defining and measuring patient satisfaction in other health departments, little attention is given to patient satisfaction with radiological services in Nigeria. However, within the hospital system, radiological services play a major role in influencing patient satisfaction. Their high throughput, diverse mix of patient population and disease entities, procedure-related discomfort including uncomfortable feelings, and examination types, ranging from routine imaging to emergency examinations, pose unique challenges ${ }^{4}$. In radiological services, patient care involves all the care that is given to patients before, during, and after radiological procedures to make the conditions of the patient better and has a great role in influencing patient satisfaction. Practical experience has shown that patients usually react to some factors that create problems in the radiology department, such as delay, neglect, use of harsh words, unnecessary repetition, and preferential treatment. Patients that arrive at the radiology department are often worried or apparently have an aggressive attitude ${ }^{2}$.
Although many studies have been conducted on patient satisfaction with radiological services, no published work especially in this part of the country was found to buttress the impact of Radiographers', Radiologist and the entire staff of radiology department that could influence patients' satisfaction. This study was carried out to determine the level of patient satisfaction with radiological care and to investigate the factors that may account for differences in patient satisfaction between a public and a private health facility in the Kano metropolis, North-western Nigeria.

\section{Materials and Methods}

A cross-sectional prospective survey study was conducted at the radiology department of one public and one private health facility in Kano State, North Western Nigeria. The same questionnaires were administered for the public and private hospitals without any changes. Ethical clearance to conduct the study was obtained from the research ethical committee at the ministry of health Kano State and patient consent was sought. A total of 140 structured questionnaires were issued to patients who visited the radiology department of the aforementioned health facilities for radiological procedures, and all of them were collected from the patients after completion. The questionnaire consists of six parts, $A, B, C, D, E$, and $F$.

PART "A" consists of socio-demographic data of the respondents This section also had a question asking the respondent whether the examination was performed on the day it was requested or not.; PART "B" consists of reception services, and ranges from question one (1) to eight (8); PART "C" consists of patients' waiting area which comprises questions ranging from one (1) to six (6); PART "D" consists of questions ranging from one (1) to nine (9) on the diagnostic room services; PART "E" consists of hospital toilets dedicated for patients use which comprises questions ranging from one (1) to five (5); PART "F" consists of patient results, comprising questions ranging from one (1) to four (4). The questions had five (5) possible answers with regard to the overall rating of patient satisfaction with each section. The data was analysed using the Statistical Package for Social Science (SPSS version 20). The results were presented 
in frequencies and percentages. A chi-square test was used to test for the differences in the level of patient satisfaction at $(p<0.05)$. Additionally, cross tabulation was performed to ascertain different factors that may affect patient satisfaction with radiological services in both public and private health facilities. The prices vary between the public and private hospitals. However, public hospitals are affordable and the prices range between 3 US dollars and 10 US dollars depending on the radiological procedure, while the price of private hospitals is slightly higher, between 5 US dollar and 20 US dollars. All payment was made via hospital cashiers stationed within various departments in the hospital.

\section{Results}

The study was carried out in two hospitals, one public and one private. The total number of distributed questionnaires was 140 with a return rate of $100 \%$. About 90 (64.29\%) were distributed to the public hospital and 50 (35.71\%) to the private hospital. In the public hospital, the number of male respondents was 40 (44.4\%), while the frequency of female respondents was 50 (55.6\%). However, At the private hospital, the frequency of male and female respondents was $15(30.0 \%)$ and $35(70.0 \%)$ respectively. The highest number of respondents that visited the radiology department at both hospitals are within the age range of 21-30 years, with the frequency of $41(45.6 \%)$ at the public and $22(44.0 \%)$ at the private hospital, while the least number of respondents are within the age range of 61-70 years, with the frequency of $4(4.4 \%)$ at the public hospital and $1(2.0 \%)$ at the private hospital.

The highest number of respondents that visited the radiology department of both public and private hospitals in this study for radiological investigations are married people, with the frequency of $42(46.7 \%)$ at the public hospital and $38(76.0 \%)$ at the private hospital, while the least number of the respondents at the public hospital are divorced people with the frequency of $2(2.2 \%)$, while the frequency of divorced people at the private hospital was $1(2.0 \%)$. Majority of the respondents $40(44.4 \%)$ at the public hospital were students in training and those in the private hospital were civil servants representing 18 (36.0\%), while others are the least in both hospitals.
The above diagram shows that $48.89 \%$ of the respondents were very satisfied, $41.11 \%$ were satisfied, 3.33\% were neither satisfied nor dissatisfied, $1.11 \%$ were very dissatisfied, and 5.56\% were dissatisfied with all radiology services at the public hospital examined in this study.

The above diagram shows that $50 \%$ of the respondents were very satisfied, $42 \%$ were satisfied, $4 \%$ were neither satisfied nor dissatisfied, none were very dissatisfied and $4 \%$ were dissatisfied with all radiology services at the private hospital studied.

The table above shows that $80 \%$ of the respondents from the private hospital were satisfied, while only $47.8 \%$ of those at the public hospital were satisfied with the radiological services received. Only $20 \%$ of the respondents at the private hospital were not satisfied with the radiological services received, while $52.2 \%$ of the respondents from the public hospital were not satisfied. This shows that patients who visited the radiology department of the private health facility were more satisfied with the services than those who visited the public health facility.

A chi-square test was used to test the differences in patient satisfaction levels in both types of health facilities and P-value $=0.000$, which showed that there is statistically significant association between private health facilities and satisfaction with radiological services because the $p$-value was $<0.05$.

\section{Discussion}

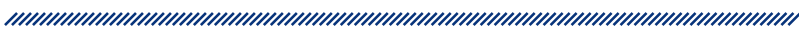

The results of this study have revealed that many factors, such as long patient waiting time in the reception and waiting area, lack of entertainment (a functional TV) in the waiting area, unavailability of a good changing room and changing gown, radiographers not introducing themselves to the patients, and lack of clear explanation of the procedure to the patients in the diagnostic room before the procedure is carried out, poor quality of toilets for patients, delayed patient results, and lack of explanation of the results to the patient lead to patient dissatisfaction with radiological services in both public and private health facilities. $15.6 \%$ of the respondents waited for more than one hour in the wait- 


\begin{tabular}{|c|c|c|c|c|}
\hline \multirow[b]{2}{*}{ Socio-demographic variables } & \multicolumn{2}{|c|}{ PUBLIC HOSPITAL } & \multicolumn{2}{|c|}{ PRIVATE HOSPITAL } \\
\hline & $\begin{array}{c}\text { Characteristic } \\
\text { Frequency }\end{array}$ & Percentage (\%) & $\begin{array}{c}\text { Characteristic } \\
\text { Frequency }\end{array}$ & Percentage (\%) \\
\hline $\begin{array}{c}\text { Age range } \\
10-20 \\
21-30 \\
31-40 \\
41-50 \\
51-60 \\
61-70\end{array}$ & $\begin{array}{c}7 \\
41 \\
23 \\
11 \\
4 \\
4\end{array}$ & $\begin{array}{c}7.8 \\
45.6 \\
25.6 \\
12.2 \\
4.4 \\
4.4\end{array}$ & $\begin{array}{c}5 \\
22 \\
16 \\
4 \\
2 \\
1\end{array}$ & $\begin{array}{c}10.0 \\
44.0 \\
32.0 \\
8.0 \\
4.0 \\
2.0\end{array}$ \\
\hline $\begin{array}{l}\text { Marital Status } \\
\text { Single } \\
\text { Married } \\
\text { Widow } \\
\text { Separated } \\
\text { Divorced }\end{array}$ & $\begin{array}{c}40 \\
42 \\
6 \\
2 \\
-\end{array}$ & $\begin{array}{c}44.4 \\
46.7 \\
6.7 \\
2.2 \\
-\end{array}$ & $\begin{array}{c}11 \\
38 \\
- \\
- \\
1\end{array}$ & $\begin{array}{c}22.0 \\
76.0 \\
- \\
- \\
2.0\end{array}$ \\
\hline $\begin{array}{l}\text { Tribe } \\
\text { Hausa } \\
\text { Fulani } \\
\text { Igbo } \\
\text { Yoruba } \\
\text { Others }\end{array}$ & $\begin{array}{c}48 \\
23 \\
6 \\
5 \\
8\end{array}$ & $\begin{array}{c}53.3 \\
25.6 \\
6.7 \\
5.6 \\
8.9\end{array}$ & $\begin{array}{c}34 \\
12 \\
- \\
1 \\
3\end{array}$ & $\begin{array}{c}68.0 \\
24.0 \\
- \\
2.0 \\
6.0\end{array}$ \\
\hline $\begin{array}{l}\text { Occupation } \\
\text { Student } \\
\text { Civil servant } \\
\text { Farmer } \\
\text { Trader } \\
\text { Others }\end{array}$ & $\begin{array}{c}40 \\
23 \\
2 \\
13 \\
12\end{array}$ & $\begin{array}{c}44.4 \\
25.6 \\
2.2 \\
14.4 \\
13.3\end{array}$ & $\begin{array}{c}15 \\
18 \\
- \\
3 \\
14\end{array}$ & $\begin{array}{c}30.0 \\
36.0 \\
- \\
6.0 \\
28.0\end{array}$ \\
\hline $\begin{array}{c}\text { Education } \\
\text { Primary } \\
\text { Secondary } \\
\text { Tertiary } \\
\text { Qur'an } \\
\text { None }\end{array}$ & $\begin{array}{c}8 \\
17 \\
57 \\
6 \\
2\end{array}$ & $\begin{array}{c}8.9 \\
18.9 \\
63.3 \\
6.7 \\
2.2\end{array}$ & $\begin{array}{c}1 \\
12 \\
35 \\
1 \\
1\end{array}$ & $\begin{array}{c}2.0 \\
24.0 \\
70.0 \\
2.0 \\
2.0\end{array}$ \\
\hline $\begin{array}{c}\text { Radiological Services Conventional X-ray } \\
\text { Digital radiography } \\
\text { Fluoroscopy } \\
\text { Angiography } \\
\text { Computed tomography imaging } \\
\text { Ultrasonography }\end{array}$ & $\begin{array}{c}46 \\
10 \\
2 \\
1 \\
14 \\
17\end{array}$ & $\begin{array}{c}51.1 \\
11.1 \\
2.2 \\
1.1 \\
15.6 \\
18.9\end{array}$ & $\begin{array}{l}19 \\
- \\
1 \\
- \\
- \\
30\end{array}$ & $\begin{array}{c}38.0 \\
- \\
2.0 \\
- \\
- \\
60.0\end{array}$ \\
\hline $\begin{array}{l}\text { When the research was conducted } \\
\text { The same day after medical exam } \\
\text { 1-2 days after medical exam } \\
\text { 3-4 days after medical exam } \\
\text { 5-6 days after medical exam } \\
7 \text { days after medical exam }\end{array}$ & $\begin{array}{c}31 \\
47 \\
6 \\
- \\
6\end{array}$ & $\begin{array}{c}34.4 \\
52.2 \\
6.7 \\
- \\
6.7\end{array}$ & $\begin{array}{c}33 \\
9 \\
3 \\
4 \\
1\end{array}$ & $\begin{array}{c}66.0 \\
18.0 \\
6.0 \\
8.0 \\
2.0\end{array}$ \\
\hline
\end{tabular}




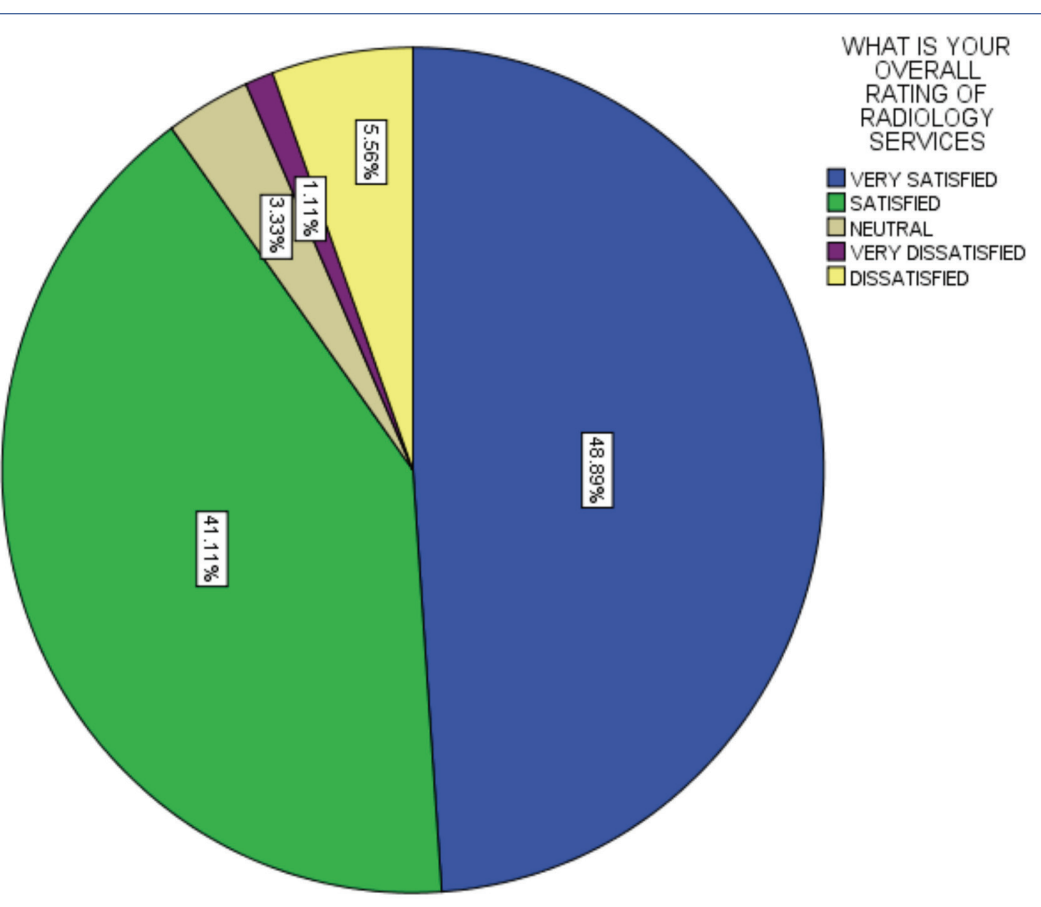

Figure 1. Overall rating of radiology services in the public hospital

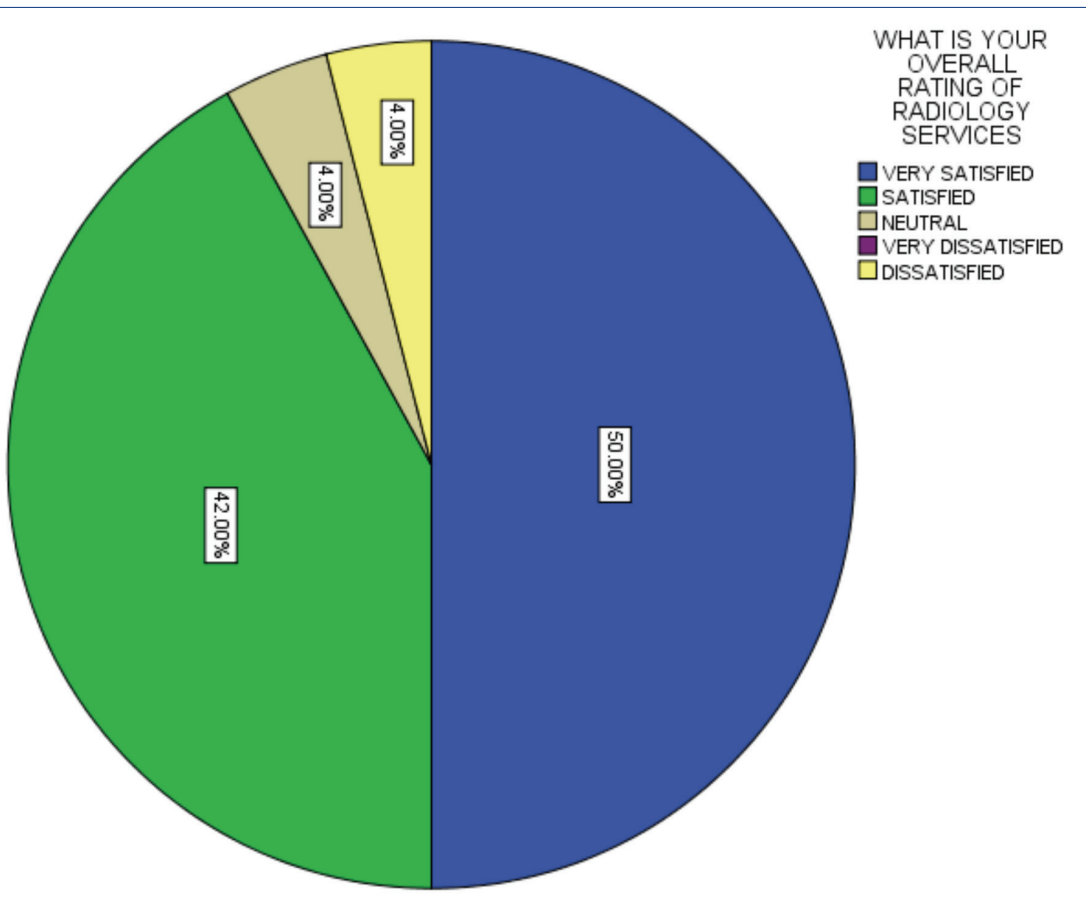

Figure 2. Overall rating of radiology services in the private hospital 


\begin{tabular}{|c|c|c|}
$\begin{array}{c}\text { Table 2. Patients' satisfaction level - comparison of the level of patient satisfaction between } \\
\text { private and public health facilities }\end{array}$ \\
\hline & Frequency & Percentage (\%) \\
\hline Public & 57 & 40.7 \\
\hline Private & 83 & 59.3 \\
\hline Total & 140 & 100.0 \\
\hline
\end{tabular}

\begin{tabular}{l} 
Table 3. Association between the type of health facility and patient satisfaction \\
\hline \multicolumn{6}{|c|}{ Cross tabulation } \\
\hline
\end{tabular}

ing area before being attended to. This is in line with the study conducted by Nwobi et al. $(2014)^{5}$, which showed that $21.4 \%(n=15)$ of patients also waited for up to one hour before being attended to. This led to their dissatisfaction since most patients prefer to spend more time inside the diagnostic room than the reception or waiting area. $56.0 \%(n=28)$ of the respondents from the private hospital were very dissatisfied with a lack of a functional television set in the waiting area, which makes the place uninteresting, and the patients get easily tired and upset when kept waiting for a long time.

The following factors influenced patient satisfaction with radiological services in our study: short waiting time, as patients who spent less time at a radiology department seem to be more satisfied than those who spent more time. This is in line with a study conducted by Ochonma et al. $(2016)^{1}$, which reported that time is highly valued by customers and that they would like to spend as little of it as possible for any business engagement. Businesses that add values to their personal income seriously manage their customers' time effectively. The explanation of the procedure to the patient before it is carried out and the personnel introducing themselves to the patient influences their satisfaction as it reduces patient anxiety and fear of the unknown. This is similar to the study by Ochonma et al. (2016) ${ }^{1}$, according to which explanation of what to expect during examination is highly valued by customers, especially in radiology examination, as customers feel anxi- ety because of the unknown. This is especially true of the elderly and those patients experiencing a radiology examination for the first time. The way questions were answered by the radiographer/staff and explanation of what to expect after the exam are both equally important for customer retention. Additionally, using a chi-square test to examine the differences in patient satisfaction level between public and private health facilities in Kano has shown that $80 \%$ of the respondents who visited the private hospital were satisfied with the radiological services received, while only $47.8 \%$ of those who visited the public hospital for radiological services were satisfied. While $52.2 \%$ of the respondents from the public hospital were dissatisfied, only $20 \%$ of the respondents from the private hospital were dissatisfied. P-value $=0.000$ implies that there is a statistically significant association between attending private health facilities and being satisfied with the services because the $P$-value was $<0.05$. Factors such as patient waiting time, cost of services, patient privacy, quality of patient toilets, personnel-patient interaction, friendliness and politeness of the staff, explanation of the procedure to the patient, waiting time before receiving the results, and explanation of the results to the patient all account for the differences in patient satisfaction levels. Indicators such as marital status had no statically significant association (P-value 0.323 ) with the level of patient satisfaction, as married respondents (64.7\%) in both hospitals were more satisfied than unmarried ones $(56.2 \%)$. Also, age had no statically significant as- 
sociation with the level of satisfaction ( $p$-value $=0.596$ ). Moreover, younger respondents (61.3\%) were more satisfied than older ones (56.9\%). Finally, respondents gender had no statistically significant with the level of satisfaction (P-value $=0.105)$, the highest number of respondents that visited radiology departments were females, and $64.7 \%$ were more satisfied than male respondents, as only $50.9 \%$ of the male respondents were satisfied. This result reflects Doghaither et al. $(2001)^{6}$, where it was shown that women were more satisfied with primary health care services than men.

\section{Conclusion}

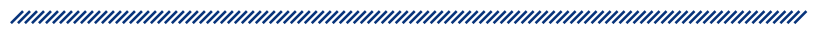

The patients in the private health facility were more satisfied than those in the public health facility because of prompt attention given to them immediately after arrival, immediate collection of their radiological reports, and a highly ergonometric environment provided by the hospital staff.

\section{References}

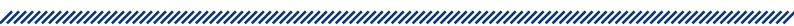

1. Ochonma, O G. Eze, B S. and Eze, C U. 'Differentials in patients' satisfaction with routine radiological services: A cross-sectional study in a developing country', African Journal of Business Management; 2016. 10(18), 429-439. doi 10.5897/AJBM2016.8093.

2. Mulisa, T. Tessema, F. and Merga, H. 'Patients' satisfaction towards radiological service and associated factors in Hawassa University Teaching and referral hospital '. BMC Health Services Research, 2017. 1-11. doi: 10.1186/ s12913-017- 2384-z.

3. Ayat, N. and Khalid, M. 'Consumer Satisfaction in Social Security Hospital': a Case Study of Punjab Employees Social Security Institution Hospital , Rawalpindi', 2009 1-25.

4. $\quad$ Ekpe EE. and Peter AL. 'Surgical patient satisfaction with services at a tertiary hospital in South-South State of Nigeria', Journal of Medical Research; 2016. 2(5)157-162.

5. Nwobi, IC. Luntsi, G. Ahmadu, MS. Nkubli, FB. Kawu, HD. Dauda, F. Moi, AS. Abubakar, GM. Tahir, MB. (2014) 'The assessment of patient perception and satisfaction of radiology waiting time in university of maiduguri teaching hospital', Kanem Journal of Medical Sciences (8)1:19-26

6. Al-Doghaither, A. Abderlrhman, B, Saeed, AAW. Al-Kamil, AA. Majsoub, MM. 'Patients' Satisfaction with Primary Health Care Centres Services in Kuwait City, Kuwait'. J Family Community Med. 2001.Sep-Dec; 8(3): 59-65.

7. Zira J.D. 'Patient satisfaction and perception of care during obstetrics ultrasound scan' at Abubakar Tafawa Balewa University Teaching Hospital Bauchi, Nigeria. Pakistan Journal of Radiology',2017. 27 (3):195-199. 


\section{ISTRAŽIVANJE ZADOVOLJSTVA PACIJENATA RADIOLOŠKIM USLUGAMA U JAVNIM I PRIVATNIM ZDRAVSTVENIM USTANOVAMA U SAVEZNOJ DRŽAVI KANO}

\section{Sažetak}

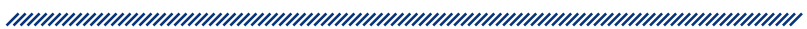

Uvod: Zadovoljstvo pacijenta jest predodžba pacijenta o stupnju u kojem određeni pružatelj zdravstvene usluge zadovoljava njegove zahtjeve i očekivanja. Ispitivanje zadovoljstva pacijenata zdravstvenim uslugama sve više dobiva na važnosti u Nigeriji, gdje se ta tema tek počinje proučavati.

Cilj: Cilj je ovog istraživanja bio usporediti zadovoljstvo pacijenata radiološkim uslugama te izdvojiti čimbenike koji mogu objasniti razlike između zadovoljstva pacijenata javnim i privatnim zdravstvenim ustanovama u saveznoj državi Kano u Nigeriji.

Postupak: Ovo je prospektivno presječno istraživanje proučilo odgovore pacijenata koji su posjetili odjele za radiologiju. Podaci su prikupljeni s pomoću upitnika s 43 pitanja oblikovanog u skladu s ciljevima istraživanja. Podaci su grupirani i analizirani primjenom statističkog programa za društvene znanosti verzije 20.0 kojim se opisne statistike poput postotaka i frekvencija generiraju i tabuliraju. Hi-kvadrat test primijenjen je kako bi se ispitale razlike u razini zadovoljstva pacijenata $(p<0,05)$.

Rezultati: Rezultati su pokazali da je 60,7\% ( $n=85)$ ispitanika bilo ženskog spola, a 39,3 \% muškog. Nezadovoljno je bilo $52,2 \%(n=47)$ pacijenata javne bolnice, dok je 47,8 \% ( $n=43)$ bilo zadovoljno. U privatnoj je bolnici samo $20 \%(n=10)$ ispitanika bilo nezadovoljno, dok je $80 \%(n=40)$ bilo zadovoljno radiološkim uslugama. Ustanovljeno je kako su vrsta zdravstvene ustanove i zadovoljstvo pacijenata statistički značajni $(p<0,05)$.
Zaključak: Pacijenti privatne zdravstvene ustanove bili su zadovoljniji od onih u javnoj zdravstvenoj ustanovi zbog brzine kojom im je pružena pažnja nakon dolaska, brzine kojom su im izdani radiološki nalazi te visokog stupnja ergonometrijskog okruženja koje im je osiguralo bolničko osoblje.

Ključne riječi: zadovoljstvo pacijenata, radiološke usluge, javne i privatne ustanove 